\title{
PENINGKATAN PARTISIPASI DAN PRESTASI BELAJAR PKn DENGAN MODEL PAKEM SISWA SEKOLAH DASAR
}

\section{INCREASING PARTICIPATION AND LEARNING ACHIEVEMENT CIVICS EDUCATION THROUGH PAKEM MODEL AT ELEMENTARY SCHOOL}

\author{
Nurhayati \\ Sekolah Dasar Negeri Turi 1 \\ Alamat email: n_1970@yahoo.com
}

\begin{abstract}
Abstrak: Penelitian ini bertujuan untuk mengetahui Peningkatan Partisipasi dan Prestasi belajar Pendidikan Kewarganegaraan (PKn) melalui Model PAKEM pada siswa kelas V SD Negeri Turi 1 Sleman Semester 1 Tahun pelajaran 2013/2014. Penelitian ini dilaksanakan di kelas V SD Negeri Turi 1 Sleman. Penelitian dengan menggunakan Pendekatan Penelitian Tindakan Kelas ( Classroom Action Research), dengan tiga siklus. Tehnik Pengumpulan Data dalam penelitian ini dengan menggunakan observasi, angket dan tes hasil belajar PKn. Instrumen yang digunakan dalam penelitian ini adalah pedoman hasil belajar PKn. Tehnik analisis data yang digunakan dalam penelitian ini adalah deskriptif kualitatif dan deskriptif kuantitatif, dengan prosentasi. Model Pembelajaran aktif, Kreatif, Efektif, dan menyenangkan (PAKEM) dikatakan mampu meningkatkan Partisipasi Belajar Pendidikan Kewarganegaraan (PKn), apabila partisipasi telah mencapai $>80 \%$, dan dapat meningkatkan prestasi dengan nilai rata-rata $\geq 71,00$ atau $=$ Kriteria Ketuntasan Minimal. Hasil Penelitian dalam tiga siklus menunjukkan bahwa partisipasi belajar dan prestasi belajar PKn dapat ditingkatkan melalui Pembelajaran Aktif, Kreatif, Efektif dan Menyenangkan (PAKEM), pada Siswa Kelas V SD Negeri Turi 1, Sleman, Semester 1 Tahun Pelajaran 2013/2014. Bukti peningkatan ditunjukkan dengan meningkatnya tingkat partisipasi belajar. Prestasi belajar pra siklus $=47 \%$, siklus $\mathrm{I}=63 \%$, siklus $\mathrm{II}=$ $76 \%$ dan siklus III $=89 \%$. Prestasi belajar PKn pra siklus $=64,86$; siklus I $=66,97$, siklus $\mathrm{II}=66,84$ dan siklus III $=82,10$.
\end{abstract}

Kata Kunci: Model Pembelajaran Pakem, Prestasi Belajar

\begin{abstract}
This study aims to determine Increased participation and learning achievement Citizenship Education (Civics) through Model PAKEM in Class V SD Negeri 1 Sleman Turi Semester 1 2013/2014 school year. This study was conducted in class V SD Negeri 1 Sleman Turi. Research using Class Action Research Approach (Classroom Action Research), with three cycles. Data collection techniques in this study using observations, questionnaires and test results of learning civics. The instrument used in this study is the result of learning civics guidelines. Data analysis techniques used in this research is descriptive qualitative and quantitative descriptive, with a percentage. Learning Model Active, Creative, Effective, and fun (PAKEM) is said to be capable of increasing the participation of Citizenship Education Study (Civics), where participation has reached $>80 \%$, and can improve performance with average grade $\geq 71.00$ or completeness $=$ Minimum Criteria , Results in three cycles showed that participation Civics learning and learning achievement can be enhanced through Active, Creative, Effective and Fun (PAKEM), in Class V SD Negeri 1 Turi, Sleman, Semester 1 Academic Year 2013/2014. Evidence of improvement shown by the increasing participation rates of learning. Learning achievement of pre-cycle $=47 \%$, the first cycle $=63 \%$, the second cycle $=76 \%$ and the third cycle $=89 \%$. Civics learning achievement of pre-cycle $=64.86$; Cycle $\mathrm{I}=66.97$, second cycle and third cycle $=66.84=82.10$.
\end{abstract}

Keywords: Pakem Learning Model, Achievement 


\section{Pendahuluan}

Dalam kehidupan suatu bangsa, pendidikan memegang peranan penting untuk maju mundurnya suatu bangsa yang ditentukan oleh tingkat kecerdasan masyarakatnya. Undang-undang No. 20 tahun 2003 tentang Sistem Pendidikan Nasional terdapat perubahan salah satu pilar pendidikan, yaitu penyempurnaan kurikulum berbasis kompetensi. Kurikulum tersebut adalah Kurikulum Tingkat Satuan Pendidikan (KTSP). Penyempurnaan kurikulum tersebut diharapkan akan memenuhi beberapa komponen pilar pendidikan. Komponen-komponen pilar pendidikan yang sangat mendasar untuk mencapai pendidikan meliputi : motivasi siswa, partisipasi siswa, materi pembelajaran yang tercover dalam administrasi pendidikan. When given the curriculum in the form of a basal or other curricular guide, accepted practice is to follow the book, (David Warren Saxe, 1953: 4).

Proses pembelajaran yang penuh inovasi dan kreasi akan dapat meningkatkan partisipasi belajar siswa. Partisipasi belajar siswa yang tinggi akan berpengaruh pada tingkat tercapainya prestasi belajar siswa. Selama ini dalam proses belajar mengajar Pendidikan Kewarganegaraan (PKn) di SD Negeri Turi 1 belum sesuai dengan yang diharapkan. Guru selama mengajar selalu berharap dirinya sebagai subjek yang harus diperhatikan, sedangkan para siswa berperan sebagai objek sehingga wajib untuk memperhatikan guru sepenuhmya sampai proses pembelajaran berakhir. Dengan demikian, proses pembelajaran yang berlangsung menjadi pembelajaran satu arah, tidak terjadi interaksi timbal balik. Pendekatan pembelajaran yang digunakan dalam proses pembelajaran selama ini masih menggunakan model tradisional. Guru kurang variatif dan kreatif dalam penggunaan metode, kurang memanfaatkan media belajar. Proses belajar mengajar berlangsung monoton. Berbagai macam metode dan macam pendekatan pembelajaran belum dimanfaatkan secara maksimal. Metode ganda atau metode gabungan belum dikembangkan dalam proses pembelajaran. Pembelajaran yang Aktif, Kreatif, Efektif, dan Menyenangkan (PAKEM) belum menjadi model pembelajaran pilihan. Proses belajar mengajar yang tidak menggunakan pendekatan (model) belajar dan metode belajar yang tepat akan berakibat mengganggu perkembangan siswa baik emosional, kreatifitas, maupun perkembangan daya nalar dan daya pikir siswa.

Penelitian tindakan kelas adalah penelitian yang dilakukan oleh guru di dalam kelasnya melalui refleksi dini dengan tujuan untuk memperbaiki kinerjanya sebagai guru, sehingga hasil belajar siswa menjadi meningkat (Wardini dkk, 2001: 48). Tujuan pengajaran dapat dicapai melalui proses yang melibatkan siswa.

Berdasarkan identifikasi masalah yang ditemukan pada pembelajaran PKn siswa kelas V SD N Turi 1, peneliti mencoba mencari penyebab mengapa siswa sulit dan kurang memusatkan perhatian dalam pembelajaran PKn. Tujuan penelitian tindakan kelas ini untuk mengetahui bagaimana upaya meningkatkan partisipasi siswa melalui model PAKEM terhadap pembelajaran Pendidikan Kewarganegaraan (PKn) sehingga prestasi belajar siswa kelas V SD N Turi 1, Sleman mengalami peningkatan.

\section{Kajian Pustaka}

1. Pengertian Partisipasi

Partisipasi dalam Kamus Besar Bahasa Indonesia mempunyai arti perihal turut berperan serta dalam suatu kegiatan; keikutsertaan; peran serta. Partisipasi berasal dari bahasa Inggris yaitu "participation" yang berarti pengambilan bagian atau pengikutsertaan. Menurut Ensiklopedi pendidikan partisipasi adalah suatu gejala demokrasi di mana orang diikutsertakan dalam perencanaan serta pelaksanaan dan juga ikut memikul tanggung jawab sesuai dengan tingkat kematangan dan tingkat kewajibannya. Dalam penelitian ini partisipasi yang dimaksud adalah partisipasi siswa yaitu keikutsertaan atau keterlibatan dalam kegiatan yang dilaksanakan dalam pembelajaran. Dari beberapa pengertian di atas, maka dapat ditegaskan bahwa partisipasi adalah keterlibatan mental dan emosi serta fisik peserta didik dalam memberikan respon terhadap kegiatan yang dilaksanakan dalam proses belajar mengajar serta mendukung pencapaian tujuan dan bertanggung jawab atas keterlibatannya. Berdasarkan pengertian di atas dapat diketahui bahwa dalam partisipasi terdapat unsur-unsur sebagai berikut: 
a) Keterlibatan peserta didik dalam segala kegiatan yang dilaksanakan dalam proses belajar mengajar.

b) Kemauan peserta didik untuk merespon dan berkreasi dalam kegiatan yang dilaksanakan dalam proses belajar mengajar.

Partisipasi siswa dalam pembelajaran sangat penting untuk menciptakan pembelajaran yang aktif, kreatif, dan menyenangkan. Dengan demikian tujuan pembelajaran yang sudah direncanakan bisa dicapai semaksimal mungkin.

Penggunaan strategi dan model yang tepat akan menentukan keberhasilan kegiatan belajar mengajar. Model belajar mengajar yang bersifat partisipatif yang dilakukan guru akan mampu membawa siswa dalam situasi yang lebih kondusif karena siswa lebih berperan, serta lebih terbuka dan sensitif dalam kegiatan belajar mengajar.

2. Pengertian Belajar

Untuk memahami pengertian belajar di sini akan diawali dengan mengemukakan beberapa definisi tentang belajar. Ada beberapa pendapat para ahli tentang definisi belajar. Cronbach, Harold, dan Geoch dalam Sardiman A.M (2005: 20) sebagai berikut:

a) Cronbach memberikan definisi: "Learning is shown by a change in behavior as result of experinence".

Belajar adalah memperlihatkan perubahan dalam perilaku sebagai hasil dari pengalaman.

b) Harold Spears memberikan definisi: "Learning is to observe, to read, to initiade, to try something themselve, to listen, to follow direction".

Belajar adalah mengamati, membaca, berinisiasi, mencoba sesuatu sendiri, mendengarkan, mengikuti petunjuk/arahan.

c) Geoch, mengatakan: "Learning is change in performance as a result of practive".

Belajar adalah perubahan dalam penampilan sebagai hasil praktek.

Dari ketiga definisi di atas dapat disimpulkan bahwa belajar merupakan perubahan tingkah laku atau penampilan, dengan serangkaian kegiatan misalnya dengan membaca, mengamati, mendengarkan, meniru dan lain sebagainya. Belajar akan lebih baik jika subjek belajar itu mengalami atau melakukannya, tidak bersifat verbalistik. Belajar sebagai kegiatan individu sebenarnya merupakan rangsangan-rangsangan individu yang dikirim kepadanya oleh lingkungan. Dengan demikian terjadinya kegiatan belajar yang dilakukan oleh seorang individu dapat dijelaskan dengan rumus antara individu dan lingkungan.

3. Pengertian Prestasi Belajar

Menurut Kamus Besar Bahasa Indonesia, prestasi diartikan sebagai hasil yang dicapai dari apa yang dikerjakan atau yang sudah diusahakan. Belajar adalah berusaha memahami sesuatu, berusaha untuk memperoleh ilmu pengetahuan, berusaha agar dapat terampil mengerjakan sesuatu. Menurut Singgih D. Gunarsa (1980), prestasi belajar merupakan hasil maksimal yang dapat dicapai oleh siswa setelah melakukan usaha belajar. Winkel (1996:226) mengemukakan bahwa prestasi belajar merupakan bukti keberhasilan yang dicapai oleh seseorang. Menurut Sri Rukmini (1983), prestasi belajar diartikan sebagai kecakapan yang nyata dan langsung dapat diukur melalui tes. Sehingga dapat dikatakan bahwa prestasi belajar adalah hasil dari usaha di mana menunjukkan kecakapan yang dicapai dalam suatu periode belajar.

Prestasi belajar adalah segala sesuatu yang dicapai dimana prestasi itu menunjang kecakapan seorang manusia. Kemudian ada pendapat lain mengatakan prestasi belajar adalah hasil yang dicapai setelah berusaha secara intensif sehingga hasil itu merupakan keunggulan.

4. Pendidikan Kewarganegaraan

Hakikat pendidikan kewarganegaraan adalah upaya sadar dan terencana untuk mencerdaskan kehidupan bangsa bagi warga negara dengan menumbuhkan jati diri dan moral bangsa sebagai landasan pelaksanaan hak dan kewajiban dalam bela negara, demi kelangsungan kehidupan dan kejayaan bangsa dan negara. Tujuan pendidikan kewarganegaraan adalah mewujudkan warga negara sadar bela negara berlandaskan pemahaman politik kebangsaan, dan kepekaan mengembangkan jati diri dan moral bangsa dalam perikehidupan bangsa.

\section{A. Model Pembelajaran PAKEM}


Model pembelajaran diartikan sebagai suatu rencana mengajar yang memperlihatkan pola pembelajaran terentu, dalam pola tersebut dapat terlihat kegiatan guru-peserta didik di dalam mewujudkan kondisi belajar atau sistem lingkungan yang menyebabkan terjadinya belajar pada peserta didik. Di dalam pola pembelajaran yang dimaksud terdapat karakteristik berupa rentetan atau tahapan perbuatan/kegiatan gurupeserta didik.

Pembelajaran yang aktif dan efektif juga bersifat variatif, interaktif, inspiratif, dan memberikan ruang yang cukup bagi prakata, kreatifitas, kemandirian yang sesuai dengan bakat minat dan perkembangan fisik serta psikologis peserta didik (Permendiknas No. 14 tahun 2007).

Pembelajaran yang aktif mempunyai sifat efektif. PAKEM adalah singkatan dari Pembelajaran Aktif, Kreatif, Efektif, dan Menyenangkan. Aktif dimaksudkan bahwa dalam proses pembelajaran guru menciptakan sesuatu sedemikian rupa sehingga siswa aktif bertanya, mempertanyakan, dan mengemukakan gagasan. Kreatif dimaksudkan agar guru menciptakan kegiatan belajar yang beragam sehingga memenuhi berbagai tingkat kemampuan siswa. Apabila suasana belajar mengajar menyenangkan, maka siswa dapat memusatkan perhatiannya secara penuh pada kegiatan belajar sehingga waktu curah perhatian siswa tinggi. Secara garis besar, model PAKEM dapat dideskripsikan sebagai berikut (Haryanto, 2007:5):

1. Siswa terlibat dalam berbagai kegiatan yang mengembangkan pemahaman dan kemampuan mereka dengan penekanan pada belajar melalui berbuat atau melakukan sesuatu kegiatan.
2. Guru menggunakan berbagai alat dan berbagai cara dalam membangkitkan semangat, termasuk menggunakan lingkungan sebagai sumber untuk menjadikan pembelajaran lebih menarik, menyenangkan, dan cocok bagi siswa.

3. Guru mengatur kelas dengan memajang buku-buku dan bahan belajar yang menarik dan menyediakan "pojok baca".

4. Guru menerapkan cara mengajar yang lebih kooperatif dan efektif, termasuk cara belajar kelompok.

5. Guru mendorong siswa untuk menemukan caranya sendiri dalam pemecahan suatu masalah, untuk mengungkapkan gagasan, dan melibatkan siswa dalam menciptakan lingkungan sekolah.

Guru berperan bukan sebagai penyampai informasi, tetapi bertindak sebagai pengarah dan pemberi fasilitas (director and facilitator of learnig) untuk terjadinya proses belajar mengajar. Pembelajaran kooperatif merupakan pembelajaran yang dilakukan dengan mengelompokkan siswa menjadi beberapa kelompok. Dalam kelompok mempunyai tingkat perbedaan baik kemampuan, jenis kelamin maupun usia yang dibimbing oleh guru dalam kemampuan dan tanggung jawab individual dan kelompok sesuai kekuatan dan kebutuhan siswa dalam bentuk penyelesaian tugas, saling bekerja sama dan saling membantu untuk memahami bahan pembelajaran agar terjadi peningkatan prestasi belajar.

\section{B. Kerangka Berpikir}

Prestasi hasil belajar PKn sangat dipengaruhi oleh dua faktor, yaitu faktor intern dan ekstern. Faktor intern meliputi minat, motivasi, dan partisipasi. 


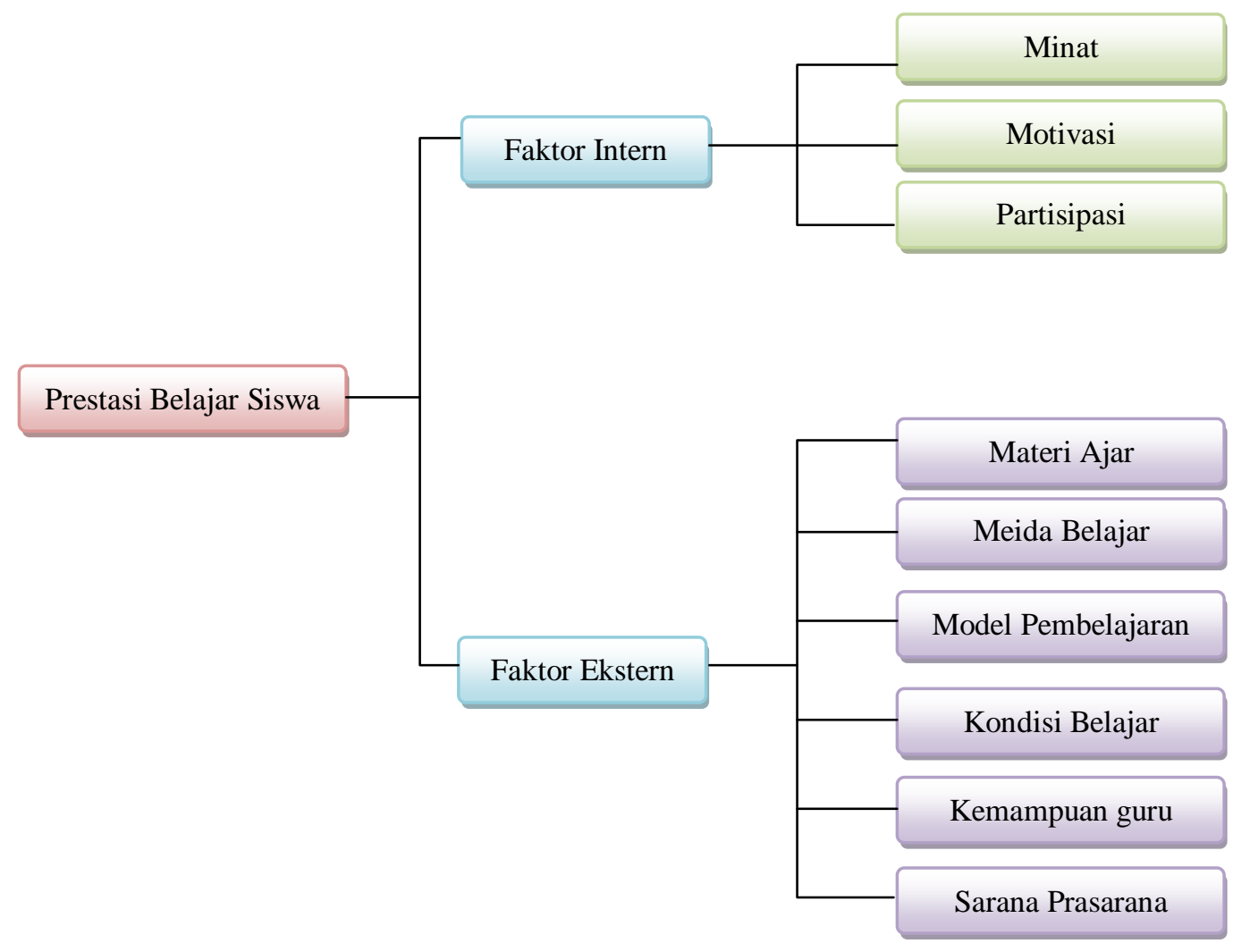

Untuk meningkatkan prestasi belajar perlu penelitian tindakan kelas. Dalam setiap tindakan dilakukan refleksi dan evaluasi. Model pembelajaran PAKEM merupakan model pembelajarn dengan kerja kelompok yang menuntut semua anggota kelompok berperan aktif untuk mendapatkan hasil kerja kelompok yang terbaik, bagi tiap-tiap kelompok. Pembelajaran model ini berpusat pada siswa (child centered), sehingga dimungkinkan partisipasi siswa akan meningkat. Guru berperan sebagai fasilitator dan moderator serta sebagai komentar dan yang berperan aktif dalam pembelajaran adalah siswa.

Melalui model pembelajaran PAKEM, suasana belajar akan lebih menarik karena siswa dituntut untuk aktif, kreatif, dan partisipatif sehingga pembelajaran diharapkan dapat lebih efektif dan menyenangkan. Siswa dapat belajar tentang kepemimpinan, bermusyawarah, percaya diri, mengemukakan pendapat, sikap percaya diri dan menghargai pendapat orang lain. Interaksi sosial antar siswa dalam satu kelompok dengan anggota kelompok lain akan terjalin. Dengan pembelajaran yang demikian akan meningkatkan partisipasi siswa dan pada akhirnya meningkatkan prestasi belajar.

\section{Metodologi Penelitian}

Penelitian ini merupakan penelitian tindakan kelas yang dilakukan secara kolaboratif dan partisipatif. Kolaboratif artinya peneliti tidak melakukan penelitian sendiri, namun berkolaborasi dengan guru senior di SD Negeri Turi 1 Sleman. Partisipatif artinya bahwa penelitian ini memerlukan partisipasi semua pihak maupun siswa, guru, pengawas maupun peneliti sendiri.

Penelitian Tindakan Kelas dilaksanakan sesuai dengan tingkat keberhasilan yang dicapai, setiap siklus dilakukan satu tindakan dalam tiap tindakan diwujudkan dalam kegiatan belajar mengajar selama satu pertemuan mata pelajaran PKn dengan waktu masing-masing mata pelajaran 2 x 35 menit. Setiap siklus penelitian terdiri dari perencanaan, tindakan, observasi, dan refleksi. Di akhir pelajaran ini guru memberikan tes akhir secara tertulis dan memberi penilaian.

Jenis data pada penelitian ini berupa data kualitatif dan data kuantitatif . Data kualitatif adalah data yang mengungkapkan kualitas yang 
akan diukur dengan diskripsi/pernyataan bukan berwujud angka. Data kualitatif diambil dari partisipasi siswa dalam proses belajar mengajar dengan metode PAKEM oleh guru. Data kuantitatif adalah data yang diukur dengan angka. Data kuantitatif ini diperoleh dari nilai pencapaian kompetensi belajar siswa. Tehnik pengumpulan data yang digunakan adalah:

1. Observasi atau pengamatan dilakukan oleh peneliti dengan cara melakukan pengamatan dan pencatatan mengenai pelaksanaan pembelajaran di kelas. Observasi dilakukan dengan menggunakan lembar observasi yang telah dipersiapan serta berupa catatan lapangan.

2. Metode wawancara dilakukan terhadap siswa dengan cara bertanya langsung kepada siswa bagaimana pendapat mereka tentang penerapan metode PAKEM dalam pembelajaran PKn. Wawancara dilakukan berdasarkan pada pedoman wawancara yang telah disusun.

3. Metode dokumentasi dilakukan dengan cara pengambilan foto saat pembelajaran berlangsung dan pengumpulan hasil tes yang telah diberikan.

4. Angket yang telah dipersiapkan, diberikan kepada siswa, kemudian siswa mengisi dan hasilnya dikumpulkan oleh peneliti.

5. Tes, soal tes dikerjakan oleh siswa secara individu dan hasilnya dikumpulkan

Data yang diperoleh dalam penelitian berupa hasil observasi dalam proses belajar mengajar, angket siswa pada akhir siklus, hasil wawancara yang dilaksanakan dengan siswa pada akhir siklus dan tes tertulis hasil belajar. Setelah data terkumpul, kemudian dianalisis dengan menggunakan metode deskripif kuantitatif.

Penelitian tindakan kelas termasuk diskriptif kuantitatif dengan salah satu tujuan untuk meningkatkan kualitas suatu fenomena atau keadaan tertentu. Seluruh data dikumpulkan dan diproses dalam tahap-tahap penelitian dianalisis dengan teknik diskriptif kuantitatif untuk mengetahui hasil penelitian dengan menyederhanakan data mentah, penafsiran data dalam bentuk naratif dan table kemudian disimpulkan. Pelaksanaan penelitian tindakan ini dalam tiga siklus dan kriteria keberhasilan dalam penelitian ini ditetapkan jika prestasi belajar siswa dalam pembelajaran PKn sebesar $71 \mathrm{ke}$ atas termasuk dalam kategori baik.

Data observasi yang telah diperoleh dihitung kemudian di prosentase. Demikian dapat diketahui sejauh mana peningkatan yang akan dicapai dalam belajar mengajar. Hasil analisa data observasi kemudian disajikan secara diskriptif.

Setiap butir pernyataan angket dikelompokkan sesuai dengan aspek yang diamati, kemudian dihitung jumlah skor pada setiap butir. Jumlah hasil skor yang diperoleh diprosentase dan dikatagorikan sesuai dengan kualifikasi hasil angket keaktifan siswa dalam belajar mengajar.

Hasil tes belajar siswa yang dilaksanakan pada akhir pertemuan ditambahkan pada skor kelompok. Nilai yang diperoleh merupakan nilai yang ditambahkan pada skor kelompok. Jika nilai yang diperoleh tinggi, maka nilai yang ditambahkan juga tinggi, dan jika nilai yang diperoleh rendah, maka nilai yang ditambahkan juga rendah.

Hasil tes belajar siswa pada akhir siklus juga dihitung nilai rata-ratanya. Hasil tes pada akhir siklus I dibandingkan dengan siklus II dan siklus III, jika mengalami kenaikan, maka diasumsikan belajar PKn dengan model PAKEM dapat meningkatkan prestasi belajar siswa.

Indikator keberhasilan yang diharapkan tiap-tiap komponen memiliki kriteria:

1. Komponen keaktifan siswa dengan kriteria : kualifikasi baik

2. Komponen kreatifitas siswa dengan kriteria : kualifikasi baik

3. Komponen efektivitas pembelajaran dalam kriteria : kualifikasi baik

4. Komponen keterlibatan siswa dalam pembelajaran dengan kriteria : kualifikasi baik

5. Komponen kerjasama siswa dalam pembelajaran dengan kriteria : kualifikasi baik

6. Tingkat partisipasi siswa dalam proses pembelajaran $>80 \%$

7. Hasil penilaian penguasaan materi pembelajaran dengan nilai rata-rata $\geq$ 71, sesuai KKM untuk siswa sebanyak $75 \%$. 


\section{Hasil Penelitian dan Pembahasan}

\section{Proses Pembelajaran sebelum Tindakan}

Sebelum dilakukan tindakan dalam pembelajaran Pendidikan Kewarganegaraan (PKn) yang diamati peneliti adalah: hasil ulangan harian pada awal semeser I tahun pelajaran 2013/2014 dan tingkat partisipai siswa dalam proses pembelajaran dengan hasil belajar.

Hasil pengamatan awal adalah: Nilai rata-rata hasil ulangan harian pada awal semester I tahun pelajaran 2013/2014 adalah 64,86 dari Kriteria Ketuntasan Minimal (KKM) yaitu 71,00. Sehingga untuk mencapai KKM, 66\% siswa harus mengikuti program remidial. Partisipasi siswa dalam mengikuti proses pembelajaran hanya $47 \%$ atau 18 anak dari 38 siswa.

Peneliti dan kolaborator mendiskusikan tentang penyebab rendahnya tingkat partisipasi dalam pembelajaran PKn. Hasil diskusi awal berkesimpulan bahwa penyebab rendahnya tingkat partisipasi siswa Berdasarkan hasil pengamatan awal dapat dinyatakan bahwa hasil belajar PKn siswa kelas V masih rendah karena tingkat partisipasi belajar yang sangat rendah.

\section{Siklus 1}

Setelah selesai pelaksanaan siklus 1, peneliti dan kolaborator mengadakan refleksi dan diskusi tentang hasil pelaksanaan kegiatan penelitian. Berdasar hasil pengamatan siklus 1 , dapat direfleksikan sebagai berikut:

a) Keaktifan siswa mengikuti pembelajaran belum optimal; dengan skor 2, kualifikasi cukup.

b) Kreatifitas siswa dalam mengikuti pembelajaran termasuk juga dalam pemecahan masalah, belum optimal; dengan skor 2, kualifikasi cukup

c) Efektivitas pembelajaran sudah baik. Proses pembelajaran sesuai dengan yang telah direncanakan, skor 3, kualifikasi baik.

d) Keterlibatan siswa dalam pembelajaran belum maksimal, baru sebagian siswa yang terlibat secara penuh, yang lainnya belum, skor 2, kualifikasi cukup.

e) Kerjasama siswa dalam satu kelompok belum terlaksana secara maksimal. Skor $=2$, kualifikasi cukup.

f) Tingkat partisipasi belajar siswa $63 \%$. g) Hasil evaluasi siswa secara individu, dengan nilai rata-rata 66,97. Nilai tertinggi 100 dan nilai terendah 30. Jumlah siswa yang remidial untuk mencapai KKM 71 adalah 23 atau $80 \%$ indikator target pencapaian belum terpenuhi.

Maka dengan mempertimbangkan hasil refleksi pada siklus 1 , peneliti dan kolaborator memutuskan untuk melanjutkan pada siklus 2 .

\section{Siklus 2}

Pelaksanaan siklus 2, peneliti dan kolaborator mengadakan refleksi dan diskusi mengenai pelaksanaan siklus 2. Berdasar hasil pengamatan dan evaluasi belajar siswa, dapat disimpulkan bahwa:

a. Keaktifan siswa mengikuti pembelajaran sudah lebih baik; skor 3, kualifikasi Baik.

b. Kreatifitas siswa dalam mengikuti pembelajaran termasuk juga dalam pemecahan masalah, belum optimal; skor 2, kualifikasi Cukup.

c. Efektifitas pembelajaran sudah berlangsung seperti yang diharapkan. Proses pembelajaran sudah lebih baik; skor 3, kualifikasi Baik.

d. Keterlibatan siswa dalam proses pembelajaran sudah bagus. Semua siswa terlibat dalam diskusi secara optimal. Skor 4, kualifikasi baik.

e. Kerjasama siswa dalam satu kelompok sudah terlaksana dengan baik, sesuai yang diharapkan. Skor 3, kualifikasi baik.

f. Tingkat partisipasi belajar siswa $76 \%$.

g. Hasil evaluasi siswa secara individu, dengan nilai rata-rata 66,84 . Nilai tertinggi 90 dan nilai terendah 10 . Jumlah siswa yang remidial untuk mencapai KKM 71,00 adalah 26 atau $68 \%$.

Dengan mempertimbangkan hasil refleksi pada siklus 2, peneliti dan kolaborator memutuskan untuk melanjutkan pada siklus 3 . Untuk mengupayakan prestasi belajar siswa, dengan indikator-indikator keberhasilan yang telah ditetapkan, maka diadakan perbaikanperbaikan ke arah penyempurnaan.

\section{Siklus 3}

Pelaksanaan siklus 3, peneliti dan kolaborator mengadakan refleksi dan diskusi mengenai pelaksanaan siklus 3. Berdasar hasil 
pengamatan dan evaluasi belajar siswa, dapat disimpulkan bahwa:

Keaktifan siswa mengikuti pembelajaran sudah sesuai seperti apa yang diharapkan oleh peneliti. Proses pembelajaran berlangsung lancar, keaktifan siswa sepenuhnya mendukung proses pembelajaran. Skor 4, kriteria kualifikasi amat baik.

a. Kreatifitas siswa dalam mengikuti pembelajaran sudah lebih baik; skor 3, kualifikasi Baik.

b. Efektifitas pembelajaran sudah baik. Pelaksanaan pembelajaran sesuai dengan Rencana Pelaksanaan Pembelajaran (RPP); skor 3, kualifikasi Baik.

c. Keterlibatan siswa dalam proses pembelajaran sudah sesuai dengan kriteria yang tertera pada lembar pengamatan. Skor 4, kualifikasi amat baik.

d. Kerjasama siswa dalam satu kelompok sudah sesuai dengan kriteria yang tertera pada lembar pengamatan; Skor 4, kualifikasi amat baik.

e. Tingkat partisipasi belajar siswa $76 \%$.

f. Hasil evaluasi siswa secara individu, dengan nilai rata-rata 82,10. Nilai tertinggi 100 dan nilai terendah 50. Jumlah siswa yang remidial untuk mencapai KKM 71,00 adalah 4 atau $10 \%$..

Menyimak hasil penelitian yang telah terlaksana 3 siklus, ternyata proses pembelajaran dengan model PAKEM merupakan suatu model pembelajaran yang dirasa efektif untuk mengajarkan proses-proses berfikir cepat, tepat dan melatih siswa fokus dalam memperhatikan suatu permasalahan. Model pembelajaran ini dapat membantu siswa membangun sendiri pengetahuannya. Ciri model pembelajaran ini adalah belajar kooperatif, kerjasama, menghargai orng lain, berfikir kritis, melatih keberanian, mampu memahami perbedaan dan keragaman pendapat.

Model pembelajaran ini juga mengembangkan sikap keterampilan sosial yang berguna bagi kemajuan dirinya, baik individu maupun kelompok. Hal ini dapat dibuktikan dengan mekanisme anggota kelompok dan kebersamaan mengerjakan dan mengatasi masalah bersama. Hal ini sesuai dengan tujuan pembelajaran $\mathrm{PKn}$, yang juga mencerminkan musyawarah seperti yang terdapat dalam sila ke 4 Pancasila, Kerakyatan yang dipimpin oleh hikmat kebijaksanaan dalam permusyawaratan / perwakilan.

Model pembelajaran PAKEM ini adalah pembelajaran aktif, kreatif, efektif dan menyenangkan, juga variatif. Variatif karena terjadi komunikasi dua arah antara guru dan siswa, juga antara siswa dengan siswa. Kontekstual yakni menghubungkan pengalaman, keadaan dan lingkungan siswa. Efektif karena dengan model pembelajaran ini dapat meningkatkan partisipasi siswa dalam belajar.

Model pembelajaran ini dilaksanakan dengan langkah-langkah: memperhatikan, membaca, mendiskusikan, presentasi, mencatat dan penilaian ternyata dapat meningkatkan partisipasi belajar siswa, sehingga dapat pula meningkatkan prestasi belajar siswa, terutama dalam pembelajaran PKn bagi siswa kelas V SD Negeri Turi 1 Sleman.

Salah satu faktor yang juga penting dalam proses pembelajaran adalah penggunaan model pembelajaran. Model pembelajaran yang tepat akan dapat memacu siswa untuk berpartisipasi dalam pembelajaran sehingga prestasinya pun akan mengalami peningkatan, demikian dengan model pembelajaran PAKEM. Model ini setidaknya dapat mendorong siswa khususnya siswa kelas V di SD Negeri Turi 1 Sleman sehingga dapat meningkatkan prestasi belajar siswa.

\section{Simpulan}

Berdasarkan hasil penelitian dan hasil pembahasan, maka dapat ditarik kesimpulan sebagai berikut:

1. Penerapan Model Pembelajaran Aktif, Kreatif, Efektif dan Menyenangkan (PAKEM) siswa kelas V SD Negeri Turi 1 Sleman dalam 3 siklus, 3 kali pertemuan dapat meningkatkan partisipasi belajar siswa dari siklus pra tindakan tingkat partisipasi sebesar $47 \%$, pada siklus 1 sebesar $63 \%$, siklus 2 sebesar $76 \%$, dan siklus 3 sebesar $89 \%$ atau terjadi peningkatan sebesar $42 \%$. Target pencapaian penelitian pada siklus 3 telah terpenuhi.

2. Penerapan Model Pembelajaran Aktif, Kreatif, Efektif dan Menyenangkan (PAKEM) juga dapat meningkatkan nilai rata-rata prestasi belajar PKn dari nilai ratarata pra tindakan 64,86 , pada siklus 1 menjadi 66,97, siklus 2 nilai rata-rata 66,84 
dan pada siklus 3 menjadi 82,10. Dengan demikian terjadi peningkatan nilai rata-rata sebesar $17,24 \%$. Target pencapaian telah terpenuhi.

\section{Daftar Pustaka}

BNSP. (2006). Standar Isi. Jakarta. Depdiknas Dirjen Mendikdasmen.

Darmiyati, Zuchdi. (2011). Pendidikan Karakter. Yogyakarta: UNY Press.

Dimyati dan Modjiono. (2002). Belajar dan Pembelajaran. Jakarta: Rineka Cipta.

Depdikbud. (1989). Kamus Besar Bahasa Indonesia. Jakarta: Balai Pustaka.

Gunarso, Singgih D. (1980). Psikologi Pengajaran. Jakarta: Grasindo.

Haryanto. (2007). Model Pembelajaran PAKEM Sekolah Dasar. Yogyakarta: Departemen Nasional Universitas Negeri Yogyakarta.
Isjoni. (2009). Pembelajaran Kooperatif Meningkatkan Kecerdasan Komunikasi antara Peserta Didik. Jakarta: Universitas Terbuka.

Kasbolah. (2001). Penelitian Tindakan Kelas. Jakarta: Universitas Terbuka.

Nasih Ahmad Mujin dan Kholidah Lilij Nur. (2009). Metode dan Tehnik Pembelajaran. Bandung: Reflika Aditama.

Sardiman, A.M. (2005). Interaksi dan Motivasi Melajar Mengajar. Jakarta: Raja Grafindo.

Sunarso. (2009). Pendidikan Kewarganegaraan Kelas 5 Sekolah Dasar. Bogor:Yudhistira.

Suharsini Arikunto. (2004). Prosedur Penelitian. Jakarta:Rineka Cipta.

Thursan Hakim. (2001). Belajar Secara Efektif. Jakarta: Puspa Swara.

Winkel, W.S. (1996). Psikologi Pengajaran. Jakarta: Grasindo. 